\title{
DETERMINATION OF CELL TYPE AND HAEMOCYTE MORPHOMETRIC CHARACTERISTICS OF WESTERN AUSTRALIA FRESHWATER CRAYFISH (Cherax cainii) AT DIFFERENT TEMPERATURES IN VITRO
}

\author{
Bambang Widyo Prastowo*12, Ricky Lareu, Rima Caccetta*3, Ravi \\ Fotedar*4
}

\begin{abstract}
The purpose of this study was to identify and morphologically characterize the hemocyte cell types of freshwater crayfish, Cherax cainii. In addition to morphological observations using a light microscope (LM) and electron transmission microscope (TEM), a flow cytometer (FCM) is also used. Three main types of haemocyte of $\underline{C}$. cainii were identified by LM, TEM, and FCM. Determination of haemocyte by LM based on the number, size of cytoplasmic granules and the ratio of $N: C$. These cells are Hyaline (HC), Small Granule (SGC), and Large Granule (LGC) cells. Three types of haemocyte were also observed by TEM based on cell and nucleus size, granule diameter, number of cytoplasmic granules per cell and $N: C$. Haemocyte population was successfully detected with FCM based on forward scatter (FSC) signals, versus side scattering signals/side scatter (SSC), with plot data via scatter parameter gating. Three cluster formations were observed, which were temporarily classified as $S G C, L G C$, and $H C$ regions. Morphometric analysis was performed with TEM on $\underline{C}$. cainii haemocyte to measure various cellular features. Some morphological features vary between types of haemocyte and are also affected by temperature. Total hemocyte count (THC) and differential hemocyte count (DHC) are calculated using FCM. THC increases with higher temperatures, from $1,9 \times 10^{6} \mathrm{ml}$ at $20^{\circ} \mathrm{C}$ to $4.9 \times 10^{6} \mathrm{lml}$ at $30^{\circ} \mathrm{C}$. The most abundant hemocyte at all temperatures is $H C$, followed by SGC and LGC.
\end{abstract}

Keywords: Freshwater crayfish, haemocyte, morphometrics, temperature, in vitro

\section{Pendahuluan}

Pada hewan dekapoda krustasea, hemosit yang bersirkulasi telah mendapat perhatian yang cukup besar sebagai mekanisme utama imunitas yang diperantarai oleh sel. Hemosit memainkan peran utama dalam reaksi imun seluler, seperti fagositosis penyerang patogen, mobilisasi melalui agregat nodular, enkapsulasi benda asing yang besar,

\footnotetext{
${ }^{1}$ E-mail: Bambang_fds@yahoo.com

${ }^{2}$ Loka Pemeriksaan Penyakit Ikan dan Lingkungan, Serang, Banten, Indonesia

${ }^{3}$ School of Pharmacy, Faculty of Health Science, Curtin University, Perth 6845, Western Australia

${ }^{4}$ School of Science, Curtin University, Perth 6845, Western Australia
} 
dan proses penyembuhan yang diikuti dengan pembekuan hemolimfa dengan cepat (Hose et al., 1990; Soderhall \& Thornqvist, 1997; Iwanaga, 2002; Eddy et al., 2007; Vazquez, 2009). Kerentanan dan ketidakteraturan sel-sel imun krustasea, di samping terbatasnya pengetahuan tentang perkembangan dan diferensiasi sel imun, membuat sulit untuk mengklasifikasikan hemosit ke dalam kelas ontogenik yang didefinisikan secara morfologis dengan baik. Secara umum mereka diperjelas dengan skema morfologis dan immuno-fungsional yang lebih seragam dari klasifikasi sel darah putih vertebrata (Zhang et al., 2006). Kemampuan untuk memisahkan dan mengisolasi populasi hemosit merupakan faktor utama tidak hanya untuk mengkarakterisasi hemosit berdasarkan fungsi seluler dan humoral, tetapi juga untuk memahami interaksi sel-sel dan studi perkembangan. Kebanyakan penyelidikan hemosit dilakukan dengan menggunakan metode sitologi atau biokimia tradisional, dengan mikroskop cahaya sebagai teknik analitis yang paling umum. Namun, adanya subjektivitas yang menonjol dalam teknik ini dan seringkali dapat menghasilkan kontroversi. Mikroskop fase kontras atau mikroskop cahaya medan terang (LM) dan mikroskop transmisi elektron (TEM) umumnya digunakan untuk mengevaluasi jumlah dan ukuran butiran dan juga rasio nukleusterhadap-sitoplasma (N:C), yang penting untuk klasifikasi morfologi (Ding et al., 2012). Namun demikian, keunggulan penggunaan flow cytometer (FCM) dibandingkan dengan metode konvensional ini menawarkan beberapa keuntungan. Metode ini sangat sensitif dan memungkinkan analisis multiparameter secara efisien. Xue et al. (2001) menambahkan informasi bahwa FCM menggunakan autofluoresensi, penanda fluorescent dan parameter hamburan cahaya untuk mempelajari ukuran dan kompleksitas sel, termasuk beberapa fungsi seluler.

Krustasea semakin dikenal sebagai hewan budidaya potensial dalam industri akuakultur, sehingga pemantauan fungsi kekebalan tubuh mereka dan meminimalkan tekanan yang dapat menyembunyikan kekebalan mereka sangat penting. Perubahan fungsi kekebalan tubuh dapat disebabkan oleh variasi lingkungan. Faktor lingkungan yang paling penting kemungkinannya adalah suhu air karena memiliki efek langsung pada asupan oksigen, metabolisme, moulting, pertumbuhan dan kelangsungan hidup (Chen et al., 1995; Hennig \& Andreatta, 1998). Variasi suhu sering menyebabkan stres bagi krustasea, menghasilkan penurunan fungsi kekebalan yang dinilai berdasarkan jumlah hemositnya, aktivasi proPO, aktivitas fagosit, dan pelepasan radikal oksigen bebas (Le Moullac et al., 2000). Sebelumnya, Vargas-Albores et al. (1998) dan Le Moullac \& Haffner (2000) melaporkan bahwa berbagai variasi pada pro-fenoloksidase (proPO) bergantung pada suhu. Oleh karena itu, efek dari respons variasi suhu pada krustasea akan memberikan informasi yang penting secara ekologis.

Tujuan dari penelitian ini adalah untuk mengidentifikasi dan mengkarakterisasi secara morfologis 
tipe sel hemosit dari lobster air tawar atau dikenal dengan sebutan Marron, C. cainii, dan untuk membandingkan hasil ini dengan spesies invertebrata yang telah diselidiki lebih teliti. Persamaan dan perbedaan di antara spesies dicatat dan diukur. Selain pengamatan morfologis menggunakan LM dan TEM, kami juga menggunakan teknik FCM yang lebih baru. Dalam penelitian ini kami juga menyelidiki proses fagositosis pada hemosit C. cainii. Parameter yang diuji adalah tantangan suhu dan imunologi dengan Vibrio mimicus yang hidup dan yang dibunuh-panas serta Escherichia coli yang dibunuhpanas secara in vitro.

\section{Metode}

Bagan pengujian efek suhu yang berbeda pada hemosit C. cainii

Pengujian untuk mengetahui efek dari suhu dilakukan seperti diuraikan pada bagan di bawah ini (Gambar 1). Tiga perangkat tangki plastik silinder untuk pengujian yang masing-masing diisi dengan 3 ekor marron dipertahankan pada suhu 20 , 25 dan $30^{\circ} \mathrm{C}$ selama dua minggu sebelum digunakan. Hemolimfa dari tiga ekor marron dari masing-masing perangkat pengujian dikumpulkan dan dihitung dan digunakan untuk pengujian ini. Pengujian dilakukan pada suhu 20, 25 dan $30^{\circ} \mathrm{C}$ dan hemosit dimasukkan ke dalam sumuran micro plate sebanyak tiga kali ulangan yang mengandung sekitar satu juta hemosit. Analisis mikroskop elektron transmisi (TEM) dan flow cytometric (FCM) dilakukan pada ketiga tipe sel hemosit (HC, SGC dan LGC).

\section{Prosedur Pengujian}

Sistem Aklimatisasi

Sistem aklimatisasi diatur di laboratorium yang dirancang khusus untuk penelitian akuakultur dengan fasilitas akuarium dalam ruangan milik Curtin Aquatic Research Laboratory (CARL), Universitas Curtin, Perth Australia Barat. Unit pengujian adalah tangki plastik silinder (diameter $80 \mathrm{~cm}$ dan tinggi 50 $\mathrm{cm}$ dan kapasitas 250 1). Tangki diisi dengan air tawar dan dilengkapi dengan aerasi konstan serta sistem filtrasi biologis resirkulasi (Fluval 205, Askoll, Italia). Air dalam tangki mengalir terus menerus, pada laju sekitar 3 1/menit. Untuk menjaga suhu konstan 20,25 , dan $30 \pm 2{ }^{\circ} \mathrm{C}$ di tangki aklimatisasi, setiap tangki dilengkapi dengan termostat submersible. Tangki itu juga dilengkapi dengan tempat perlindungan bagi marron yang cukup jumlahnya dalam bentuk pipa PVC dengan diameter yang sesuai ukuran tubuhnya. 


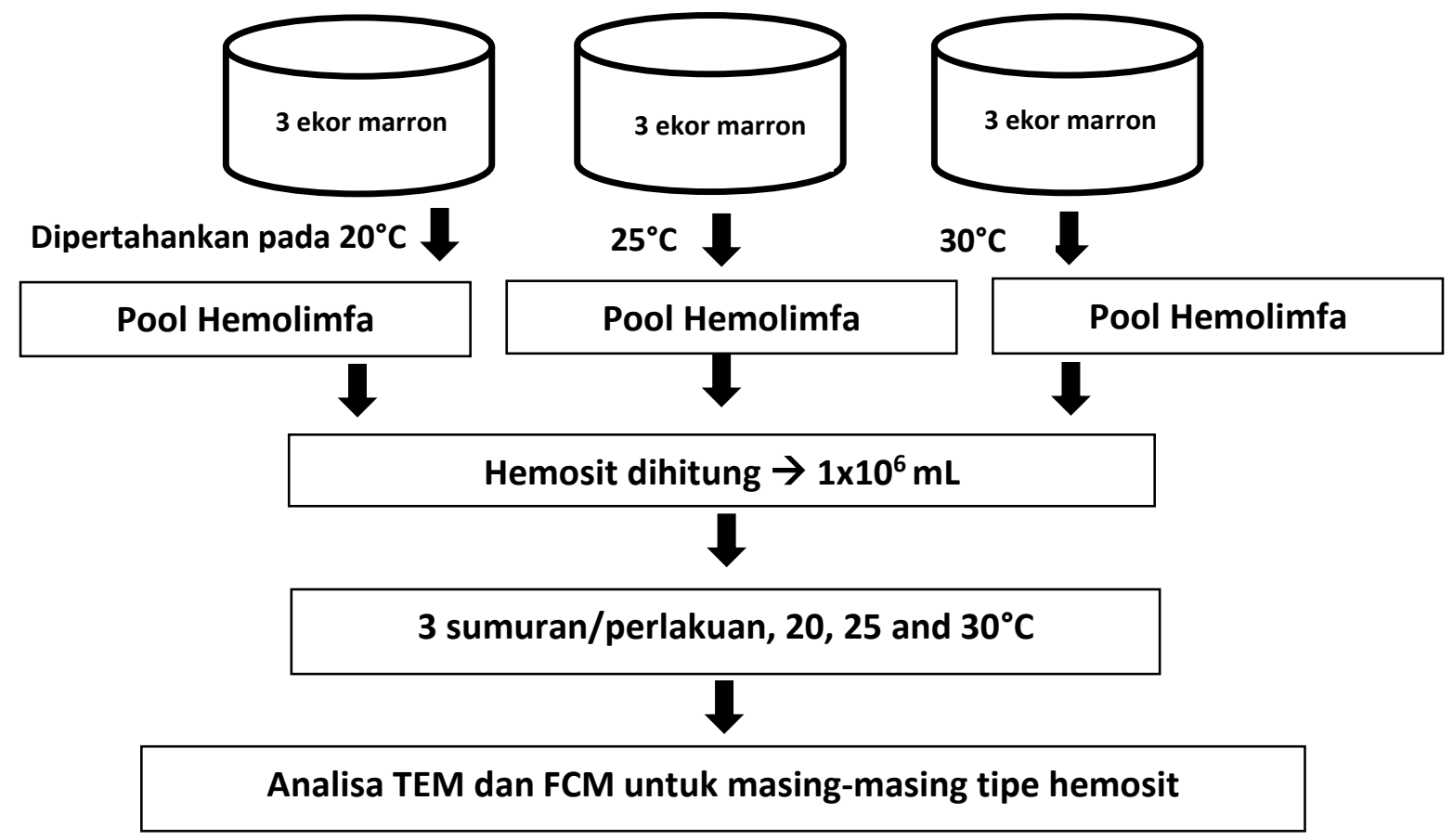

Gambar 1. Bagan pengujian efek suhu yang berbeda pada hemosit Cherax cainii

\section{Hewan Uji}

Marron jantan $( \pm 150 \mathrm{~g})$ dibeli dari Aquatic Resource Management Pty Ltd., Manjimup, Australia Barat 6258. Hewan uji tersebut diberi makan dengan pakan pelet komersial yang mengandung $26 \%$ protein, 47 $50 \%$ karbohidrat, $9 \%$ lemak, dan 8,9 $\%$ abu (Enviroplus Pty Ltd., Perth, Australia) hingga percobaan dimulai. Marron diberi makan pada sore hari sebanyak $3 \%$ berat badan/2 hari. Makanan yang belum dimakan dibuang dengan jalan disiphon. Sebelum penggunaan untuk pengujian, hewan uji diaklimatisasikan pada kondisi laboratorium selama satu minggu. Hanya hewan uji yang tampak sehat yang dipergunakan.

\section{Persiapan Hemosit}

Marron dibius dengan air yang diisi dengan es selama 15 menit, dan sekitar $2 \mathrm{ml}$ hemolimfa diekstraksi per hewan uji dengan jarum suntik 5ml dengan jarum $25^{1} / 2 \mathrm{G}$ yang berisi volume yang sama dari buffer sitrat/EDTA yang didinginkan sebelumnya (0,45 M NaCI; 0,1 M M glukosa; $30 \mathrm{mM}$ trisodium sitrat; 26 $\mathrm{mM}$ asam sitrat dan $10 \mathrm{mM}$ EDTA) $\mathrm{pH} 4,6$, sebagai larutan antikoagulan (AB). Hemolimfa yang telah dilarutkan ulang didistribusikan ke dalam tabung mikrosentrifus steril 10 $\mathrm{ml}$ yang terpisah yang disimpan di dalam pecahan es dan disentrifugasi pada 500x G selama 5 menit pada suhu $4{ }^{\circ} \mathrm{C}$. Supernatan dibuang dan masing-masing pelet sel dilarutkan ulang dalam $2 \mathrm{ml} \mathrm{AB}$ dingin. Sampel tersebut kemudian dipindahkan ke tabung mikrosentrifus terpisah yang diletakkan didalam es. Setetes sampel yang telah dilarutkan ulang dipindahkan ke hemositometer untuk dihitung selnya dengan mikroskop cahaya (Olympus) dan diwarnai 
dengan trypan blue. Hanya sel yang dipersiapkan dengan viabilitas lebih tinggi dari $90 \%$ yang digunakan. Sampel yang telah dilarutkan ulang yang tersisa diencerkan dengan $\mathrm{AB}$ untuk mendapatkan konsentrasi akhir sekitar $1 \times 10^{6} \mathrm{sel} / \mathrm{ml}$.

\section{Mikroskop Transmisi Elektron}

Dalam persiapan untuk mikroskop transmisi elektron (TEM), $1 \mathrm{ml}$ hemolimfa yang diencerkan dengan $\mathrm{AB}$ dikumpulkan dari masing-masing 3 ekor marron. Hemolimfa ini kemudian disentrifugasi pada 500x G selama 5 menit pada suhu $4{ }^{\circ} \mathrm{C}$. Pelet hemosit pertama kali dipasca fiksasi dengan glutaraldehid $5 \%$ yang disiapkan dalam buffer fosfat ( $\mathrm{pH} 7,3$ ) selama 2 jam hingga semalam pada suhu $4{ }^{\circ} \mathrm{C}$ dan kemudian difiksasi dengan asam osmat krom Dalton $1 \%$ dalam buffer yang sama pada suhu $4{ }^{\circ} \mathrm{C}$ selama $1-$ $1 \frac{1}{2}$ jam. Sel-sel yang difiksasi tadi didehidrasi dalam serangkaian pencucian etanol diikuti oleh pencucian dengan propilena oksida untuk menghilangkan sisa etanol yang sebelumnya digunakan untuk dehidrasi sebelum diproses secara rutin untuk proses embedding secara konvensional dalam propilena oksida/resin Epoxy 812 (TAAB, UK). Bagian Ultrathin (tebal sekitar $90 \mathrm{~nm}$ ) dipotong dengan menggunakan Ultramicrotome E. Reichert (Wina, Austria) dan pisau berlian dipasang pada wadah kisi-kisi tembaga. Potongan-potongan itu kemudian diwarnai ganda dengan uranyl asetat dan timbal sitrat. Potongan tersebut diamati dan difoto dengan Philips CM100 Biotwin Transmission Electron Microscope (Eindhoven, Belanda).
Flowcytometry

Suspensi hemosit dianalisis dengan Attune Acoustic Focussing Flow Cytometer (Applied Biosystems) yang dilengkapi dengan 2 sistem laser: Laser Biru dan Merah dengan emisi yang difilter pada 488 dan $638 \mathrm{~nm}$. Filter bandpass Photomultiplier untuk fluoresensi hijau adalah 488/10 (BL1), 530/30 (BL2), 574/26 (BL3), 690/50 (BL4) dan untuk fluoresensi merah adalah 660/20 (RL1) dan 780/60 (RL2). Data sinyal hamburan ke depan (yang mengukur ukuran sel relatif) dikumpulkan pada skala linier dan data sinyal hamburan samping (yang mengukur granularitas sel) dikumpulkan pada skala logaritmik. Pengaturan tegangan adalah FSC 1350, SSC 1450, BL1 1600, BL2 2000, BL3 2000, BL4 2550, RL1 2350 dan RL2 1950. Data adalah gating FSC/SSC, dan 10.000 peristiwa secara total diperoleh per sampel. Perangkat Lunak Attune v1.2 digunakan untuk membuat wilayah logis untuk analisis data, dan perangkat lunak FlowJo digunakan untuk membuat wilayah logis untuk menganalisis persentase sel di setiap wilayah.

\section{Hasil dan Pembahasan}

\section{Penentuan Hemosit C. cainii}

Tiga jenis hemosit utama diidentifikasi dengan LM, TEM dan FCM pada $C$. cainii berdasarkan jumlah dan ukuran butiran sitoplasma dan rasio N: C. Hemosit ini adalah sel hialin (HC), sel granula kecil (SGC), dan sel granula besar (LGC). 
Penentuan Tipe Sel $\underline{\text { C. cainii dengan }}$ $L M$

Tiga jenis hemosit diamati oleh LM dalam hemolimfa $C$. cainii (Gambar 2). Mereka diidentifikasi sebagai HC, SGC dan LGC. Sel hialin adalah sel paling banyak ditemukan di
C. cainii diikuti oleh SGC. Jenis sel yang paling tidak melimpah adalah LGC. Persentase relatif dari tipe hemosit yang bersirkulasi di $C$. cainii adalah HC (50\%), SGC $(29,2 \%)$ dan LGC $(20,8 \%)$.

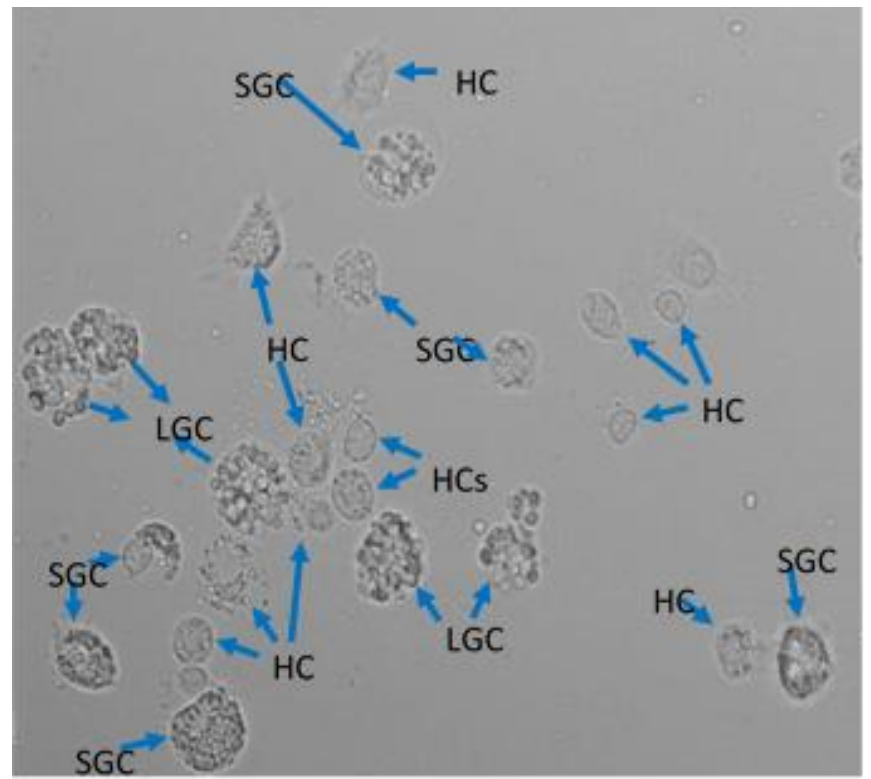

Gambar 2. Hasil pengamatan mikroskop cahaya pada haemosit Cherax cainii: sel hialin (HC), menunjukkan nukleus besar dan sitoplasma tipis, sel granula kecil (SGC) menunjukkan bentuk yang berbeda dan sitoplasma yang divakuolisasikan; sel granula besar (LGCs) menghadirkan sejumlah butiran bundar yang tersebar luas di sitoplasma

\section{Penentuan Tipe Sel $\underline{\text { C. cainii dengan }}$} TEM

Data morfologis didapatkan berdasarkan pengamatan setidaknya dari 15 haemosit dari masing-masing tipe (dikumpulkan dari 3 hemolimfa marron).

\section{Sel Hialin (HC)}

Sel-sel hialin bentuknya tidak beraturan dan memiliki nukleus besar yang dikelilingi oleh lapisan sitoplasma yang tipis, dan dengan demikian mempunyai rasio $\mathrm{N}$ : $\mathrm{C}$ yang tinggi (Gambar 3). Hemosit terkecil yang bersirkulasi ini memiliki rasio
$\mathrm{N}$ :C yang lebih tinggi daripada SGC dan LGC. Rasio N:C yang tinggi berguna untuk identifikasi mereka. Sel hialin memiliki relatif sedikit granula, berbentuk butiran bulat kecil di sitoplasma mereka. Butiran ini bisa dilihat dengan TEM tetapi tidak dengan LM. Inti HC bervariasi bentuknya, baik bentuk seperti ginjal atau ovoid, dengan atau tanpa nukleolus. Sitoplasma memiliki poliribosom yang bebas, retikulum endoplasma kasar dan sedikit (hingga 20 per bagian sel), vesikel padat elektron kecil berdiameter sekitar 0,3 $\mu \mathrm{m}$. 


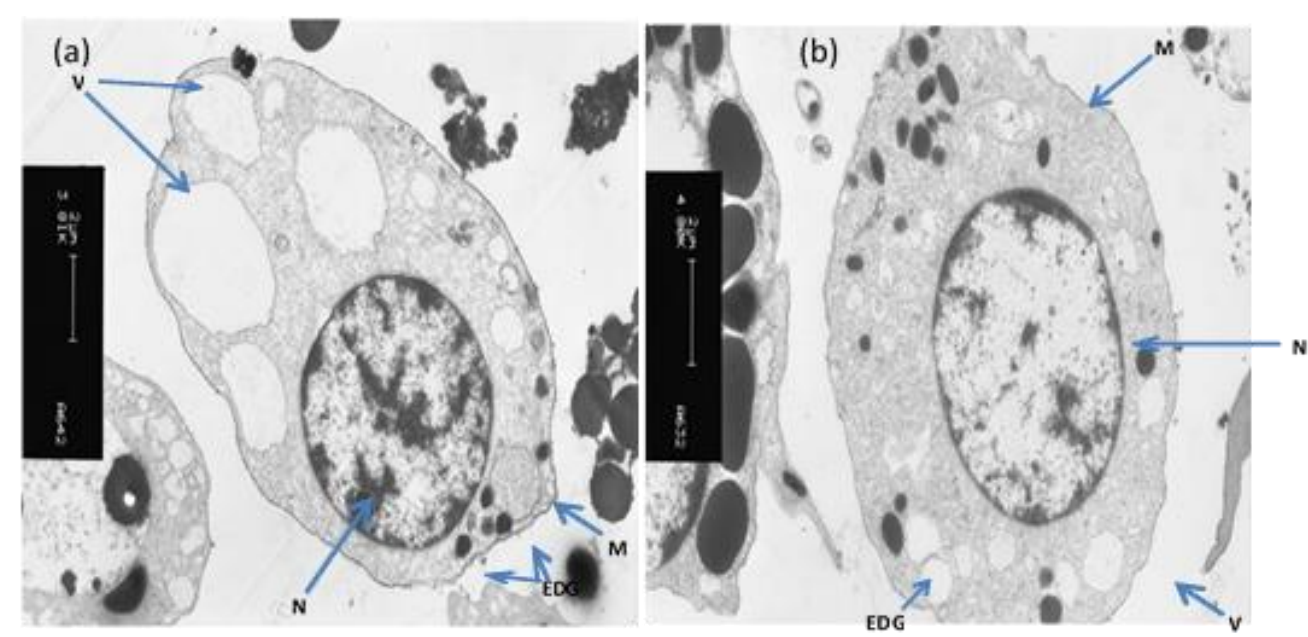

Gambar 3. Mikrograf transmisi elektron dari hemosit Cherax cainii menunjukkan sel-sel hialin (HC). EDG, butiran padat elektron; N, nukleus; V, vakuola dan M, mitokondria. Butiran hadir dalam hemosit hialin meskipun tidak banyak. Bar, $2 \mu \mathrm{m}$ $(\mathrm{a}, \mathrm{b})$

Sel Granulosa Kecil (SGC)

Sel granula kecil juga mempunyai bentuk yang tidak beraturan. Mereka secara khas menampilkan banyak butiran elektron padat, butiran bulat kecil atau bulat telur dalam jumlah sitoplasma yang relatif besar. Jumlah butiran elektron padat lebih sedikit dibandingkan dengan LGC tetapi mengandung lebih banyak butiran daripada HC. Butiran masih hanya mengisi kurang dari 30 $\%$ dari ruang sitoplasma. Ukuran butiran lebih kecil dari butiran LGC (lihat di bawah). Nukleus berbentuk bulat atau ginjal, dengan distribusi euchromatin yang lebih banyak. Ada banyak vakuola sitoplasma besar dan kecil, dan pseudopodia terus-menerus memanjang. Nukleus besar terletak di posisi sentral dengan profil polimorfik yang tidak teratur, kadangkadang melengkung. Sitoplasma mempunyai retikulum endoplasma kasar yang berkembang dengan baik, aparatus Golgi, dan mitokondria kecil (berdiameter 0,5 $\mu \mathrm{m}$ ) bulat hingga memanjang dengan krista tabular. SGC memiliki rasio N:C dua kali dari LGC (Gambar 4). 


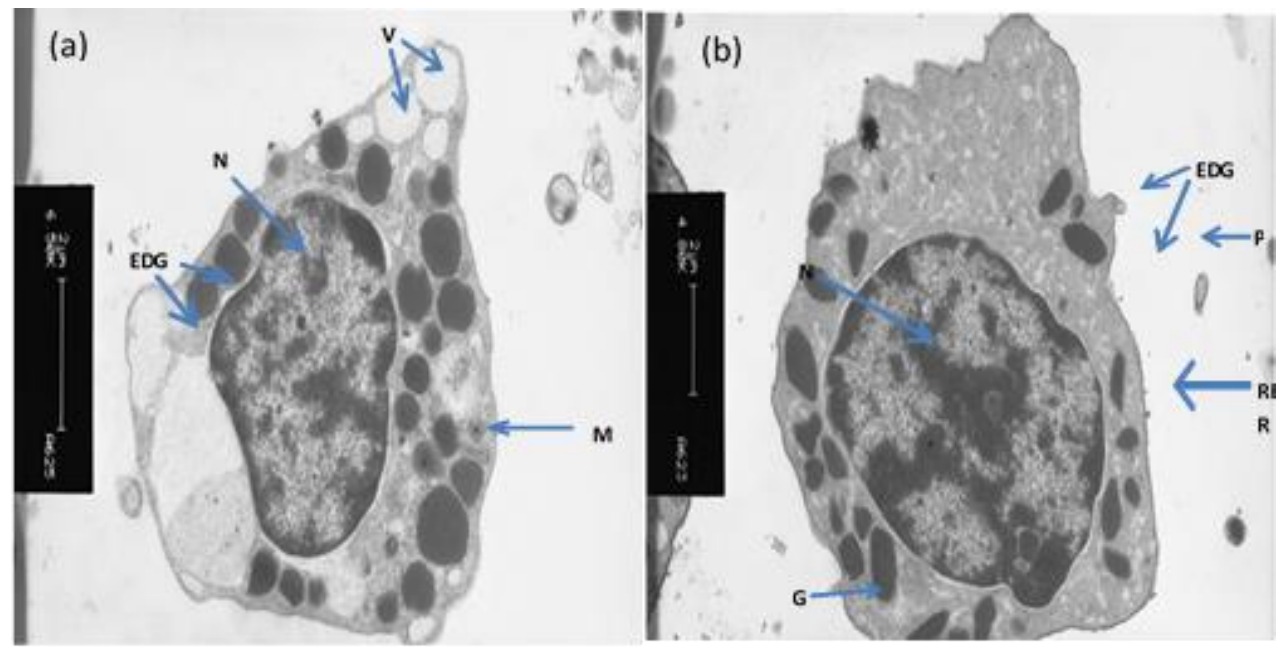

Gambar 4. Mikrograf transmisi elektron hemosit dari Cherax cainii yang menunjukkan tipe granula kecil (SGC). EDG, butiran padat elektron; N, nukleus; $\mathrm{V}$, vakuola; RER, retikulum endoplasma kasar; G, golgi dan M, mitokondria; P, pseudopodia. Bar, $2 \mu \mathrm{m}(\mathrm{a}, \mathrm{b})$

\section{Sel Granula Besar (LGC)}

Sel granula besar berbentuk bulat atau bulat telur (Gambar 5). Mereka dicirikan dengan butiran padat, besar, kurang struktur, tertutup membran elektron yang menunjukkan profil butiran seperti bulat-oval dengan diameter maksimum hingga $2,1 \mu \mathrm{m}$ yang mengisi sebagian besar sitoplasma. Butirannya lebih besar dari pada HC dan SGC, dan jumlahnya lebih besar, menempati lebih dari $50 \%$ ruang sitoplasma. Sel bulat atau bulat telur ini memiliki nukleus yang relatif kecil, dengan rasio N:C yang relatif rendah. Sitoplasma dipenuhi dengan banyak butiran besar yang kadang-kadang mengaburkan nukleus. Ketika dilihat oleh TEM, nukleus LGC berbentuk ginjal yang menunjukkan massa kromatin terkondensasi dan nukleat bilobate. Ada lebih sedikit organel, tetapi tampak beberapa vakuola sitoplasma besar. Pseudopodia juga meluas ke pinggiran sel. 


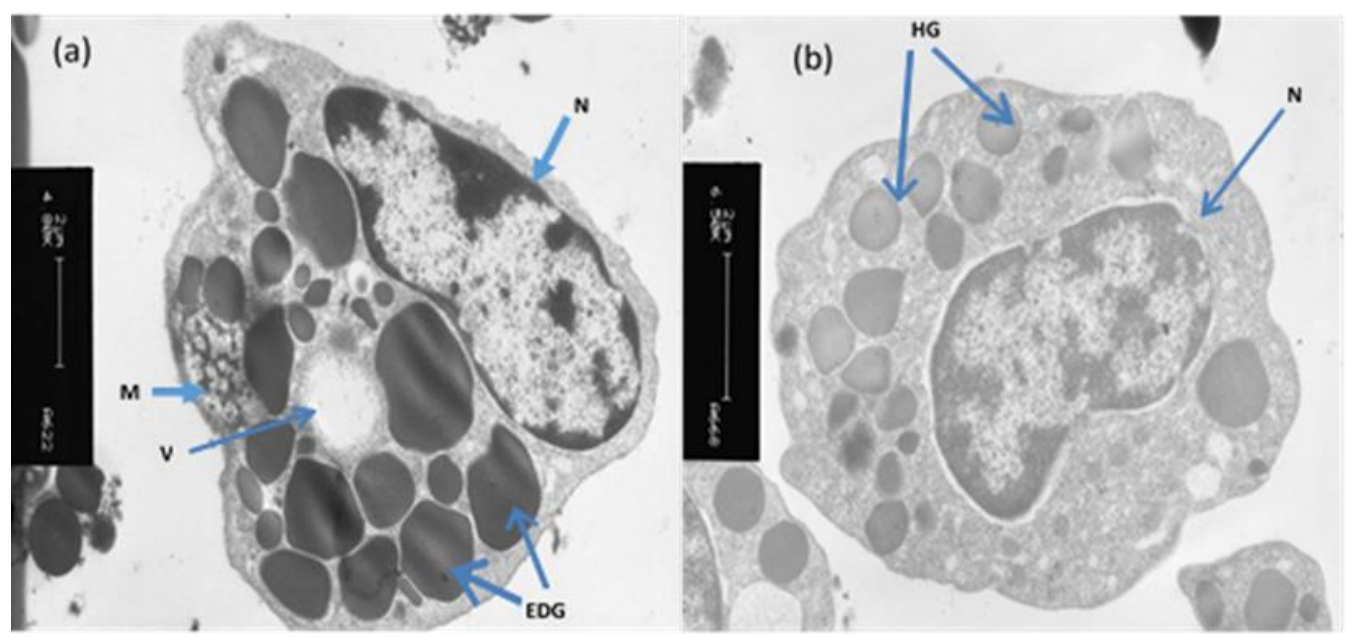

Gambar 5. Mikrograf transmisi elektron hemosit dari Cherax cainii yang menunjukkan tipe granula besar (LGC). EDG, butiran padat elektron; N, nukleus; $\mathrm{V}$, vakuola dan $\mathrm{M}$, mitokondria

\section{Penentuan hemosit $\underline{C \text {. cainii dengan }}$} FCM

Populasi hemosit berhasil dideteksi dengan sinyal hamburan ke depan (FSC), yang mengukur ukuran sel relatif, dibandingkan hamburan samping (SSC), yang mengukur granularitas sel dengan plot data melalui scatter parameter gating.

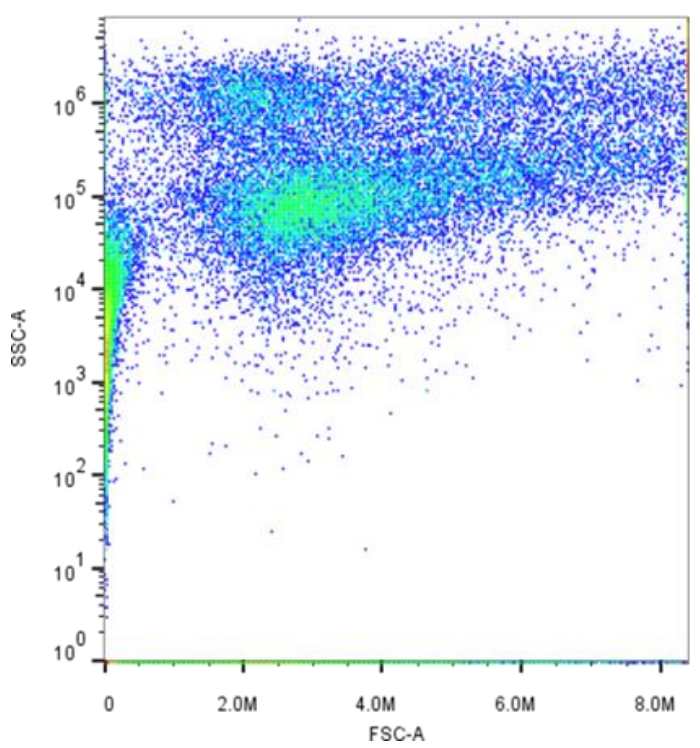

Tiga bentukan kluster diamati dalam hemogram khas FSC versus SSC (Gambar 6a). Gating digambar di sekitar setiap bentukan kluster (Gambar 6b), yang sementara diklasifikasikan sebagai wilayah SGC (R1), LGC (R2) dan HC (R3) dalam satu parameter dot-plot dalam skala $\log$.

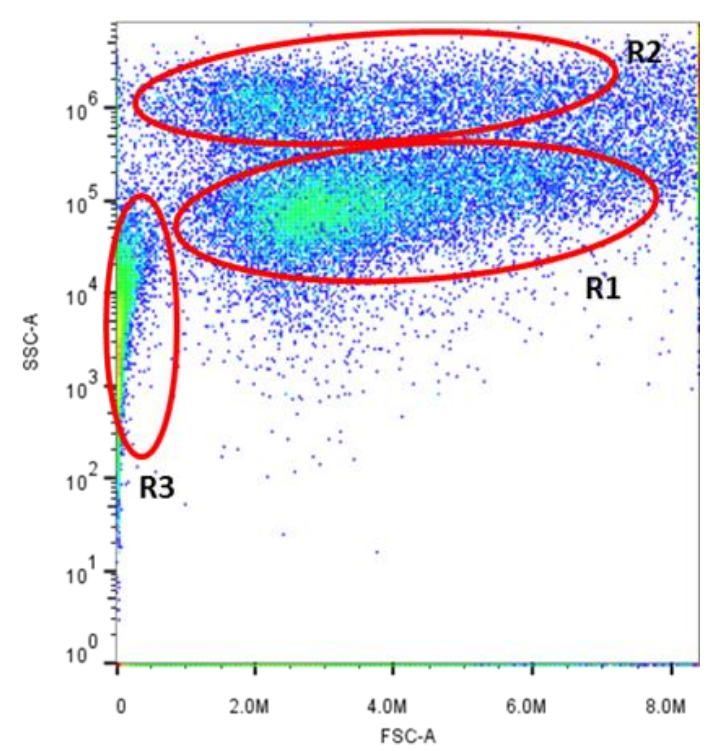

Gambar 6. Flow sitogram dari hemosit Cherax cainii. (a) Dot plot hamburan ke depan (FSC) dalam skala linier versus hamburan samping (SSC) dalam skala logaritmik. (B) Dot plot FSC dan SSC pada hemosit dari Cherax cainii 
menunjukkan tiga populasi sel diduga: R1 (sel granula kecil), R2 (sel granula besar), dan R3 (sel hialin)

Karakteristik Morfometrik

Morfometrik Hemosit C. cainii

Berdasarkan pengamatan

dengan TEM, tiga populasi hemosit yang jelas sesuai dengan analisis berdasarkan LM dan FCM:HC, SGC dan LGC. Analisis morfometrik dilakukan pada hemosit untuk mengukur berbagai fitur seluler. Fitur tersebut adalah ukuran sel, ukuran inti, diameter butiran, jumlah butiran sitoplasma per sel dan rasio $\mathrm{N}: \mathrm{C}$ (Tabel 1).

Tabel 1. Analisis morfometrik fitur hemosit Cherax cainii.

\begin{tabular}{|c|c|c|c|c|c|c|c|}
\hline \multirow{2}{*}{\multicolumn{2}{|c|}{$\begin{array}{l}\text { Tipe Hemosit } \\
\text { Temperatur }\end{array}$}} & \multicolumn{2}{|c|}{ Hialin } & \multicolumn{2}{|c|}{ Granula kecil } & \multicolumn{2}{|c|}{ Granula besar } \\
\hline & & $20^{\circ} \mathrm{C}$ & $30^{\circ} \mathrm{C}$ & $20^{\circ} \mathrm{C}$ & $30^{\circ} \mathrm{C}$ & $20^{\circ} \mathrm{C}$ & $30^{\circ} \mathrm{C}$ \\
\hline Ukuran & Panjang & $11,5(1,0)^{\mathrm{ab}}$ & $9,1(0,2)^{\mathrm{ab}}$ & $13,4(1,5)^{\mathrm{b}}$ & $12,1(0,6)^{\mathrm{b}}$ & $13,7(0,6)^{\mathrm{b}}$ & $9,5(0,3)^{\mathrm{a}}$ \\
\hline sel & Lebar & $8,9(0,3)^{\mathrm{a}}$ & $8,2(0,1)^{\mathrm{a}}$ & $8,5(0,2)^{\mathrm{a}}$ & $9,7(0,8)^{\mathrm{a}}$ & $11,1(0,7)^{\mathrm{ab}}$ & $8,1(0,2)^{\mathrm{a}}$ \\
\hline Ukuran & Panjang & $7,7(0,6)^{\mathrm{ac}}$ & $6,5(0,7)^{\mathrm{ac}}$ & $6,6(0,4)^{\mathrm{ac}}$ & $6,3(0,5)^{\mathrm{ac}}$ & $3,9(0,6)^{\mathrm{c}}$ & $3,8(0,2)^{\mathrm{c}}$ \\
\hline inti & Lebar & $5,5(0,8)^{\mathrm{c}}$ & $5,1(0,5)^{\mathrm{c}}$ & $4,6(0,4)^{\mathrm{c}}$ & $4,6(0,5)^{\mathrm{c}}$ & $3,1(0,9)^{\mathrm{c}}$ & $3,5(0,04)^{\mathrm{c}}$ \\
\hline \multicolumn{2}{|c|}{ Diameter granula } & $\begin{array}{l}0.3(0.1)^{\mathrm{d}}- \\
1.0(0.3)^{\mathrm{e}}\end{array}$ & $\begin{array}{l}0,5(0,3)^{\mathrm{d}}- \\
2,1(0,3)^{\mathrm{f}}\end{array}$ & $\begin{array}{c}0,3(0,2)^{\mathrm{d}}- \\
1,8(0,9)^{\mathrm{f}}\end{array}$ & $\begin{array}{c}0,3(0,1)^{\mathrm{d}}- \\
1,4(0,4)^{\mathrm{e}}\end{array}$ & $\begin{array}{l}0,3(0,2)^{\mathrm{d}}- \\
2,0(0,3)^{\mathrm{f}}\end{array}$ & $\begin{array}{l}0,4(0,3)^{\mathrm{d}}- \\
2,1(1,3)^{\mathrm{f}}\end{array}$ \\
\hline \multirow{2}{*}{\multicolumn{2}{|c|}{$\begin{array}{l}\text { Jumlah granula } \\
\text { Rasio N:C }\end{array}$}} & $19(2.5)^{\mathrm{g}}$ & $17(2,7)^{\mathrm{g}}$ & $29(1,0)^{\mathrm{h}}$ & $33(2,3)^{\mathrm{h}}$ & $36(2,8)^{\mathrm{h}}$ & $33(2,2)^{\mathrm{h}}$ \\
\hline & & $45.2(2.7)^{\mathrm{i}}$ & $40,5(2,4)^{\mathrm{i}}$ & $28,3(0,8)^{\mathrm{j}}$ & $25,2(0,9)^{\mathrm{j}}$ & $12,2(2,6)^{\mathrm{k}}$ & $17,3(1,0)^{\mathrm{k}}$ \\
\hline
\end{tabular}

Keterangan: Pengukuran mewakili rata-rata ( \pm kesalahan standar). Ukuran sel dan inti disajikan dalam panjang x lebar $(\mu \mathrm{m})$. Diameter butiran adalah dalam $\mu \mathrm{m}$. Jumlah butiran adalah jumlah per bagian sel. Rasio N: C dalam persen. Semua data morfometrik di atas didasarkan pada pengamatan TEM dari setidaknya 15 hemosit setiap tipenya (dikumpulkan dari 3 ekor marron) pada suhu yang berbeda. Data dalam kolom yang sama yang memiliki huruf superskrip yang sama menunjukkan rata-rata yang sama yang tidak berbeda secara signifikan $(\alpha=0,05)$

Beberapa fitur morfologis bervariasi antara jenis hemosit dan juga dipengaruhi oleh suhu. Sel hialin adalah sel terkecil dibandingkan dengan SGC dan LGC. Tidak terdapat perbedaan yang nyata dalam ukuran sel antara SGC dan LGC, baik pada 20 atau $30{ }^{\circ} \mathrm{C}$. Terdapat tren penurunan ukuran sel pada suhu yang lebih tinggi tetapi ini hanya signifikan untuk populasi LGC. Sel-sel hialin memiliki rasio $\mathrm{N}: \mathrm{C}$ tertinggi sementara LGC memiliki rasio $\mathrm{N}$ :C terendah dan juga memiliki inti yang jauh lebih kecil dibandingkan $\mathrm{HC}$ dan SGC. Tidak terdapat perbedaan yang nyata dalam ukuran granula antara ketiga jenis hemosit tetapi LGC dan SGC memiliki granula bulat kecil yang melimpah, jumlah yang jauh lebih besar daripada HC.

\section{Jumlah Total dan Diferensiasi Hemosit}

Tiga ekor marron diadaptasikan selama 2 minggu pada suhu yang berbeda $\left(20,25\right.$ dan $\left.30{ }^{\circ} \mathrm{C}\right)$ dan hemolimfanya diambil untuk dihitung jumlah total hemosit (THC) dan jumlah diferensial haemosit (DHC) menggunakan FCM. Jumlah total hemosit dalam $C$. cainii meningkat pada suhu yang lebih tinggi, naik dari 1,9 juta per ml pada $20^{\circ} \mathrm{C}$ menjadi 4,9 juta per ml pada $30^{\circ} \mathrm{C}$ (Tabel 2). Selsel granula besar meningkat secara tidak proporsional ketika THC meningkat dengan suhu, dan kedua 
tipe lainnya mengalami penurunan sebagai akibatnya. Namun, hemosit yang paling melimpah pada ketiga suhu adalah HC, diikuti oleh SGC, dengan LGC yang paling sedikit terwakili dalam jumlah.

Tabel 2. Jumlah total hemosit (THC) dari Cherax cainii pada suhu yang berbeda.

\begin{tabular}{ccccc}
\hline $\begin{array}{c}\text { Temperatur } \\
\left({ }^{\mathbf{}} \mathbf{C}\right)\end{array}$ & $\begin{array}{c}\text { THC } \\
(\mathbf{x ~ 1 0} \mathbf{~} \mathbf{~ e l} / \mathbf{m l})\end{array}$ & HC (\%) & SGC (\%) & LGC (\%) \\
\hline 20 & $1.978(0,4)^{\mathrm{a}}$ & $43,6(0,6)^{\mathrm{a}}$ & $37,5(0,5)^{\mathrm{ab}}$ & $18,9(0,9)^{\mathrm{c}}$ \\
25 & $2.869(0,5)^{\mathrm{ab}}$ & $43,2(1,1)^{\mathrm{a}}$ & $34,3(0,4)^{\mathrm{bc}}$ & $22,5(1,3)^{\mathrm{c}}$ \\
30 & $4.924(0,7)^{\mathrm{b}}$ & $40,8(0,9)^{\mathrm{a}}$ & $33,0(1,6)^{\mathrm{bc}}$ & $26,2(2,7)^{\mathrm{bc}}$ \\
\hline
\end{tabular}

Keterangan: Pengukuran mewakili rata-rata (dikumpulkan dari 3 ekor marron) \pm kesalahan standar. Data ini diperoleh dengan FCM. Data dalam kolom yang sama yang memiliki huruf superskrip yang sama menunjukkan rata-rata yang sama yang tidak berbeda secara signifikan $(\alpha=0,05)$

Diskusi

Penelitian ini menyelidiki mengenai morfologi, jumlah total dan diferensial sel hemosit pada marron. Hanya sedikit perhatian yang telah diberikan pada hemosit $C$. cainii jika dibandingkan dengan krustasea lainnya. Setelah menggunakan teknik LM, TEM dan FCM untuk melihat dan menganalisis hemosit dari spesies ini, kami mengelompokkan mereka menjadi tiga jenis sel. Sel hialin mengandung beberapa butiran sitoplasma dan SGC mengandung sejumlah granula kecil. LGC diisi dengan granula besar. Bauchau (1981) mengenali jenis sel berikut dari berbagai krustasea dan meninjaunya sebagai berikut: 1) HC dengan tidak ada atau hanya satu tubuh Golgi dan tidak ada atau sedikit granula kecil; 2) SGC dengan satu atau lebih tubuh Golgi dan sejumlah sedang granula kecil; dan 3) sel granula dengan tidak ada atau hanya satu tubuh Golgi dan banyak granula besar. Kami telah menggunakan klasifikasi yang sama, dan meskipun hanya didasarkan pada tidak adanya atau keberadaan granula dan ukuran relatifnya, hal itu memungkinkan untuk mengidentifikasi hemosit secara konsisten dengan menggunakan LM, TEM dan FCM (juga menggunakan ukuran sel). Sistem ini telah digunakan dalam banyak studi haemosit krustasea dan tidak tunduk pada variasi prosedural dan/atau interpretasi subjektif (Giulianini, et al., 2007; Sung et al., 2002).

Banyak skema klasifikasi telah menetapkan signifikansi yang sama atau lebih banyak pada beberapa karakteristik, misalnya ukuran, struktur, atau fitur pewarnaan sel. Pada udang karang, dan udangudangan lainnya, perbedaan ukuran sel tidak signifikan untuk penggunaan praktis. Struktur sel juga merupakan dasar yang tidak mencukupi untuk melakukan klasifikasi hemosit, karena sebagian besar sel adalah ovoid secara in vivo, dan strukturnya cepat berubah secara in vitro dengan menggunakan pemanjangan filipodia dan lamellipodia (Johnson, 1987). Dalam penelitian lain, Dall (1964) menggunakan perbedaan dalam bentuk sel hemosit udang (Metapenaeus mastersii) untuk membedakan jenis sel: limfosit, thigmocytes, dan amoebosit granula besar yang mirip dengan HC, SGC, dan LGC. Variasi dalam struktur hemosit mungkin disebabkan karena 
sel yang diperiksa tanpa fiksasi sebelumnya. Kejadian pseudopodia dalam dua jenis sel terakhir menunjukkan bahwa mereka telah mulai memanjang, karena hemosit krustasea lain juga telah diketahui untuk melakukan fillipodia dan pseudopodia, sementara mereka berada di dalam substrat. Karena kekurangan dari penentuan karakteristik secara tradisional (yaitu ukuran sel, bentuk, dan karakteristik pewarnaan) untuk mengklasifikasikan hemosit, kami menganggap bahwa klasifikasi hemosit menjadi tiga jenis hanya berdasarkan pada tidak adanya atau keberadaan dan ukuran granula relatif menjadi klasifikasi yang paling mudah dan konsisten yang saat ini ada.

Hemosit C. cainii dan fiturfiturnya yang berbeda dapat diamati dengan jelas menggunakan mikroskop cahaya standar. Sel-sel hialin tidak memiliki granula yang jelas, sementara SGC memiliki sedikit granula kecil yang tidak dapat dibiaskan, dan LGC memiliki banyak butiran besar yang sangat mudah dibiaskan yang sering menutupi nukleus. Namun, Ashton-Alcox \& Ford (1998) menjelaskan bahwa cukup sulit untuk menghitung jumlah granula dengan mikroskop cahaya. Selain itu, Martin \& Graves (1985) menjelaskan bahwa identifikasi beberapa fitur menggunakan metode pewarnaan standar, seperti pewarnaan dengan Wright, haematoxylin dan eosin, yang umumnya digunakan untuk mewarnai sel plasma vertebrata dengan sukses, adalah tidak informatif karena mereka seringkali tersembunyi atau tidak tepat, seringkali tidak dapat diproduksi ulang oleh peneliti lain dan akhirnya, tidak menggunakan perangkat yang memungkinkan untuk melakukan diferensiasi beberapa granula pada fase pematangan yang berbeda dan fungsi fisiologis yang berbeda. Selain itu, ketika pewarnaan tersebut diimplementasikan pada teknik ulas hemolimfa, struktur sel menjadi sangat rusak. Pada kenyataannya, kami juga berusaha menggunakan pewarnaan Wright Giemsa dengan sedikit keberhasilan (data tidak ditampilkan).

Tiga kategori hemosit juga dapat diidentifikasi dengan menggunakan TEM. Keberhasilan metode ini tergantung pada proses fiksasi sel yang akan diperiksa setelah dikeluarkan dari tubuh udang karang. Hal ini penting karena dapat membuatnya lebih mudah untuk membedakan sel-sel hemolimfa yang bersirkulasi dari perubahan morfologis sel yang bereaksi terhadap inisiasi pembekuan darah atau karena kehadiran partikel asing, misal jarum suntik atau kaca penutup. Data dalam penelitian ini merupakan catatan dari penggunaan TEM untuk pertama kali terhadap populasi hemosit $C$. cainii. Meskipun memerlukan pengorbanan waktu dan tenaga yang besar, TEM adalah teknik penting untuk investigasi respon seluler terhadap parameter lingkungan dan untuk memantau fitur yang berbeda dari sel invertebrata. Dalam studi mengenai korelasi garis keturunan dari tiga jenis hemosit pada udang Penaeid dan Palaemonid, data TEM memberikan klasifikasi yang lebih detil dari pematangan hemosit, meskipun hasilnya masih tetap menjadi pertanyaan terbuka (Martin \& Graves, 1985; Tsing et al., 1989). Menggunakan TEM, hemosit 
granular yang jarang diamati dan telah berhasil diamati dalam kasus yang tidak biasa (hanya terlihat di beberapa bagian lintas sel yang sama). Johnson (1987) mengakui bahwa morfologi hemosit krustasea berubah dengan cepat, dan membuatnya tampak sebagai tambahan kategori sel. Tiga jenis hemosit dari kepiting $C$. sapidus telah diidentifikasi dengan menggunakan TEM sebagai HC, semi granular dan sel granular (Bodammer, 1978). Penulis tersebut menemukan bahwa ada beberapa granula kecil dan peralatan Golgi yang berkembang dengan baik di $\mathrm{HC}$, dan menduga bahwa mereka tidak dapat menemukan sel tanpa granula kemungkinan karena jumlah mereka yang relatif rendah dan sifat labil mereka. Hearing and Vernick (1967) juga tidak dapat menemukan sel-sel agranular dalam hemosit lobster dengan menggunakan TEM, meskipun mereka mengidentifikasi tiga kategori hemosit yang masingmasing memiliki granula.

Sedikit yang diketahui tentang penggunaan FCM untuk menganalisa hemosit dari $C$. cainii, meskipun teknik ini lebih cepat dan menyediakan data yang lebih akurat dan kuantitatif. Dalam banyak hal, FCM telah menggantikan evaluasi secara mikroskopis karena ia menawarkan kemampuan secara cepat dan simultan untuk membedakan populasi seluler berdasarkan berbagai variabel, seperti ukuran relatif, kompleksitas / granularitas dan sifat fluoresen (Shapiro, 2003; Bakke, 2000). Namun, Ford et al. (1994) menjelaskan bahwa persentase sel dalam hemosit dari masing-masing tiram berubah dua hingga lima kali lipat dengan menggunakan FCM. Terlepas dari ketidakkonsistenan dalam beberapa penelitian, dalam penelitian ini kami memverifikasi bahwa FCM dengan dua parameter sederhana, FSC dan SSC, dapat secara efektif menentukan populasi hemosit $C$. cainii. Pengumpulan data hamburan samping pada skala logaritmik yang merupakan indikasi bahwa dibutuhkan lebih banyak daya untuk mengukur kisaran granularitas yang luas di antara populasi hemosit. Shapiro (1995) menemukan tiga faktor, selain ukuran sel, yang dapat mempengaruhi pengukuran data hamburan ke depan: perbedaan indeks bias antara sel dan media suspensi; keberadaan material, di dalam atau di atas sel, dengan penyerapan yang kuat pada panjang gelombang iluminasi yang digunakan; dan struktur internal sel. Beberapa struktur internal, misalnya granula atau vakuola, memiliki kecenderungan untuk menurunkan penyebaran cahaya ke depan; untuk alasan itu sel-sel dengan ukuran lebih besar ditempatkan dekat sumbu. Dalam penelitian ini, menggunakan FCM, kami dapat dengan jelas mengidentifikasi 3 populasi sel haemosit $C$. caini: LGC, yang memiliki ukuran sel dan jumlah granula terbesar (dalam R2); SGC yang berukuran sedang dan memiliki jumlah granula yang lebih kecil (dalam R1); dan HC, yang memiliki ukuran sel terkecil dan kompleksitas paling kecil (dalam R3). Sebagai perbandingan, sulit untuk membedakan antara SGC dan LGC dari C. cainii berdasarkan ukuran dan karakteristik morfologisnya dengan penyelidikan mikroskopis cahaya, 
karena mereka sangat mirip. Namun sel-sel ini dapat dengan mudah dibedakan menggunakan FCM. Xian et al. (2009) menggunakan FCM pada hemosit udang penaeid, Litopenaeus vannamei, dan memiliki hasil yang serupa dengan hasil penelitian kami ini. Begitu juga Comesana et al. (2012), yang menunjukkan kesamaan sub-populasi hemosit untuk tiram datar Ostrea edulis dengan populasi hemosit yang telah kami tunjukkan di sini untuk C. cainii. Di tangan kami, analisis FCM adalah teknik yang lebih disukai untuk mengidentifikasi populasi hemosit $C$. cainii, dan oleh karena itu memungkinkan evaluasi terhadap perubahan dalam proporsi relatif dari tipe-tipe hemosit ini, tentunya lebih unggul daripada LM dan TEM.

Jumlah total hemosit (THC) adalah metode praktis untuk mengevaluasi status fisiologis krustasea. Namun, ada berbagai nilai THC yang telah disampaikan tetapi karena skema klasifikasi dan metode yang digunakan berbeda yang mana adalah tidak memungkinkan melakukan perbandingan informatif antara berbagai krustasea. Faktor lingkungan seperti suhu dan salinitas juga mempengaruhi THC pada tiram Crassostrea virginica in vivo (Oliver \& Fisher, 1995). Setelah mengadaptasikan marron pada suhu yang berbeda selama dua minggu, kami telah menunjukkan bahwa terjadi perubahan yang mencolok pada $\mathrm{THC}$, dengan suhu $30^{\circ} \mathrm{C}$ yang menaikkan jumlahnya lebih dari dua kali lipat. Alvarez et al. (1989); Chu \& La Peyre, (1993); dan Hégaret, (2003) mengemukakan bahwa suhu di atas tingkat tertentu dapat mengakibatkan kondisi stres pada hemosit tiram, sebagai akibat dari mereka yang kurang reaktif. Selain itu, kapasitas penyaringan dan aktivitas metabolisme dari kerang Mediterania Chamelea gallina berkurang secara dramatis pada suhu di bawah $10{ }^{\circ} \mathrm{C}$ atau lebih dari $30{ }^{\circ} \mathrm{C}$ (Ramon \& Richardson, 1992). Perbedaan THC dalam krustasea tidak hanya disebabkan karena perbedaan suhu atau salinitas tetapi juga dapat disebabkan oleh faktorfaktor lain seperti ketersediaan makanan, jenis kelamin, diet, lama pemeliharaan dan tahap siklus molting (Stewart et al., 1967; Tsing et al., 1989; Baldaia et al., 1984; CuzinRoudy et al., 1989; Sequeira et al., 1995).

Melalui penggunaan FCM, jumlah diferensial hemosit (DHC) untuk $C$. cainii menunjukkan bahwa $\mathrm{HC}$ adalah sel yang paling melimpah, diikuti oleh SGC dan LGC yang paling sedikit jumlahnya. Peningkatan suhu dari 20 menjadi 30 ${ }^{\circ} \mathrm{C}$ menghasilkan perubahan yang kecil namun signifikan, serta terbalik pada angka SGC dan LGC. Variasi dalam DHC telah ditemukan di antara spesies krustasea yang dipengaruhi oleh faktor intrinsiknya (yaitu jenis kelamin dan tahap siklus moulting) dan faktor ekstrinsik (yaitu faktor lingkungan, diet, dan panjang penangkaran) (Lorenzon et al., 1999). Dari pengamatan mikroskopis dan FCM sebelumnya, HC adalah hemosit yang paling banyak pada beberapa spesies Penaeid (77- 89\%), (LeMoullac et al., 1997; Owens \& O'Neill, 1997) dan hemosit tiram timur, Crassostrea virginica (Ford et al., 1994; Ashton-Alcox \& Ford, 1998). Cardenas et al. (2000) juga menemukan bahwa hasil dari 
pengamatan dengan mikroskop dan FCM menunjukkan pola distribusi yang sama di antara jenis sel, meskipun nilai HC dari FCM sekitar $10 \%$ lebih rendah. Smith \& Soderhall (1983), menemukan dari hemosit monolayer lobster air tawar Astacus astacus dengan pengamatan mikroskop terdiri dari semi-granular $\sim 50 \%$ (setara dengan SGC), granular $\sim 30 \%$ (setara dengan LGC), dan HC $\sim 20 \%$. Demikian pula, populasi tipe hemosit L. vannamei yang diamati menggunakan TEM terdiri dari SGC sebagai jenis yang paling melimpah, diikuti oleh HC dan LGC (Heng \& Wang, 1998). Sequeira et al. (1995) dan Owens \& O'Neill (1997), menunjukkan hasil yang bertentangan dengan beberapa laporan lainnya, menemukan bahwa granulosit $(9-13$ $\%)$ lebih banyak daripada semigranulosit (2\%), yang mirip dengan laporan lain (Ford et al. , 1994; Ashton-Alcox \& Ford, 1998). Amen et al. (1992) tidak menemukan indikasi adanya jenis sel yang berbeda pada hemosit siput Lymnaea stagnalis dengan menggunakan FCM.

\section{Kesimpulan}

Sebagai kesimpulan, kami telah menunjukkan, melalui beberapa teknik, bahwa hemosit dari C. cainii dapat diklasifikasikan menjadi 3 tipe populasi yang konsisten dengan krustasea lain. Perbedaan jumlah hemosit untuk $C$. cainii mengungkapkan bahwa $\mathrm{HC}$ adalah sel yang paling melimpah, diikuti oleh SGC dengan LGC. Oleh karena itu, DHC dapat digunakan untuk mengevaluasi perubahan relatif dalam populasi hemosit karena faktor lingkungan yang dapat mempengaruhi sistem imunologis mereka. Untuk dapat membandingkan antara spesies krustasea yang berbeda, terdapat kebutuhan untuk menggunakan teknik yang standar. Skema klasifikasi yang kami sampaikan dalam penelitian ini menawarkan metode yang mudah dan praktis untuk mengkarakterisasi hemosit $C$. cainii dan juga sesuai dengan penelitian terkini tentang hemosit di krustasea lain. Klasifikasi yang diusulkan akan bermanfaat untuk pengembangan lebih lanjut, kemungkinan juga termasuk untuk parameter lain yang dapat memberikan informasi lebih lanjut tentang tahap perkembangan dan pematangan hemosit serta untuk mengevaluasi fungsi fisiologis mereka.

\section{Daftar Pustaka}

Alvarez, M. R., Friedl, F.E., Johnson, J.S. and Hinsch, G.W. (1989). "Factors affecting in vitro phagocytosis by oyster hemocytes." Journal of Invertebrate Pathology ${ }_{2}$ 54(2): 233 -241 .

Amen, R. I., Aten, J.A., Baggen, J.M., Meuleman, E.A., de Lange-de Klerk, E.S. and Sminia, T. (1992). "Trichobilharzia ocellata in Lymnaea stagnalis: a flow cytometric approach to study its effects on hemocytes." Journal of Invertebrate Pathology 59(1): 9598.

Ashton-Alcox, K. A. and Ford, S.E. (1998). "Variability in molluscan hemocytes: a flow cytometric study." Tissue \& Cell 30(2): 195204. 
Bakke, A. C. (2000). "Clinical applications of flow cytometry." Laboratory Medicine 31(2): 97102.

Baldaia, L., Porcheron, P., Coimbra, J. and Cassier, P. (1984). "Ecdysteroids in the shrimp Palaemon serratus: relations with molt cycle." General and Comparative Endocrinology 55(3): 437-443.

Bauchau, A.G.

"Crustaceans". In Invertebrate Blood Cells. Vol.2 (Eds. Ratcliffe, N.A. and A.F. Rowley). Academic Press. Sidney. pp. 385-420.

Bodammer, J. E. (1978). "Cytological observations on the blood and hemopoietic tissue in the crab, Callinectes sapidus. I. The fine structure of hemocytes from intermolt animals." Cell and Tissue Research 187(1): 79-96.

Cardenas, W., Jenkins, J.A. and Dankert, J.R. (2000). "A flow cytometric approach to the study of crustacean cellular immunity." Journal of Invertebrate Pathology 76(2): 112-119.

Chen, J. C. (1995). "Survival, hemolymph osmolality and tissue water of Penaeus chinensis juveniles acclimated to different salinity and temperature levels." Comparative Biochemistry and Physiology a-Molecular \& Integrative Physiology 110(3): 253-258.

Chu, F. L. E. and Lapeyre, J.F. (1993). "Perkinsus-Marinus susceptibility and defense-related activities in eastern oysters Crassostrea virginica temperature effects." Diseases of Aquatic Organisms 16(3): 223234.
Comesana, P., Casas, S.M., Cao, A., Abollo, E., Arzul, I., Morga, B. and Villalba, A. (2012). "Comparison of haemocytic parameters among flat oyster Ostrea edulis stocks with different susceptibility to bonamiosis and the Pacific oyster Crassostrea gigas." Journal of Invertebrate Pathology 109(3): 274-286.

Cuzin-Roudy, J., Strambi, C., Strambi, A. and Delbecque, J.P. (1989). "Hemolymph ecdysteroids and molt cycle in males and females of Siriella armata m. edw. (Crustacea: Mysidacea): possible control by the MI-ME X-organ of the eyestalk." General and Comparative Endocrinology 74(1): 96-109.

Dall, W. (1964). "Studies on the physiology of a shrimp, Metapenaeus mastersii (Haswell) (Crustacea: Decapoda: Penaeidae)". Australian Journal of Freshwater Resources 15: 145161.

Ding, Z., Du, J., Ou, J-T., Li, W., Wu, T., Xiu, Y., Meng, Q.G., Ren, Q., Gu, W., Xue, H., Tang, J-Q., Wang, W. (2012). "Classification of circulating hemocytes from the red swamp crayfish Procambarus clarkii and their susceptibility to the novel pathogen Spiroplasma eriocheiris in vitro." Aquaculture 356-357: 371-380.

Eddy, F., Powell, A., Gregory, S., Nunan, L.M., Lightner, D.V., Dyson, P.J., Rowley, A.J. and, Shields, R.J. (2007). "A novel bacterial disease of the European shore crab, Carcinus maenas molecular pathology and epidemiology." Microbiology 153(Pt 9): 2839-2849. 
Ford, S. E., Ashtonalcox, K.A. and Kanaley, S.A. (1994). "Comparative cytometric and microscopic analyses of oyster hemocytes." Journal of Invertebrate Pathology 64(2): 114122.

Giulianini, P. G., Bierti, M., Lorenzon, S., Battistella, S. and Ferrero, E.A. (2007). "Ultrastructural and functional characterization of circulating hemocytes from the freshwater crayfish Astacus leptodactylus: cell types and their role after in vivo artificial non-self challenge." Micron 38(1): 49-57.

Hearing, V. and Vernick, S.H. (1967). "Fine structure of the blood cells of the lobster, Homarus americanus". Chesapeake Science 8 (3): 170186.

Hégaret, H., Wikfors, G.H. and Soudant, P. (2003). "Flow cytometric analysis of haemocytes from eastern oysters, Crassostrea virginica, subjected to a sudden temperature elevation. II. Haemocyte functions: aggregation, viability, phagocytosis, and respiratory burst." Journal of Experimental Marine Biology and Ecology 293(2): 249-265.

Heng, L. and Wang, L. (1998). "On the ultrastructure and classification of the hemocytes of penaeid shrimp, Penaeus vannamei (Crustacea, Decapoda)". Chinese Journal of Oceanology and Limnology 16: 333-338.

Hennig, O. L. and Andreatta, E.R. (1998). "Effect of temperature in an intensive nursery system for Penaeus paulensis (Perez Farfante,
1967)." Aquaculture 164(1-4): 167-172.

Hose, J. E., Martin, G.G. and Gerard, A.S. (1990). "A decapod hemocyte classification scheme integrating morphology, cytochemistry, and function." Biological Bulletin 178(1): 33-45.

Johnson, P. T. (1987). "A review of fixed phagocytic and pinocytotic cells of decapod crustaceans, with remarks on hemocytes." Developmental \& Comparative Immunology 11(4): 679-704.

Iwanaga, S. (2002). "The molecular basis of innate immunity in the horseshoe crab." Current Opinion in Immunology 14(1): 87-95.

Le Moullac, G., LeGroumellec, M., Ansquer, D., Froissard, S. and Levy, P. (1997). "Haematological and phenoloxidase activity changes in the shrimp Penaeus stylirostris in relation with the moult cycle: protection against vibriosis." Fish \& Shellfish Immunology 7(4): 227-234.

Le Moullac, G. and Haffner, P. (2000). "Environmental factors affecting immune responses in Crustacea." Aquaculture 191(1-3): 121-131.

Lorenzon, S., de Guarrini, S., Smith, V.J. and Ferrero, E.A. (1999). "Effects of LPS injection on circulating haemocytes in crustaceans in vivo." Fish \& Shellfish Immunology 9(1): 31-50. Martin, G. G. and Graves, B.L. (1985). "Fine-structure and classification of shrimp hemocytes." Journal of Morphology 185(3): 339-348.

Oliver, L. M. and Fisher, W.S. (1995). "Comparative Form and Function of Oyster Crassostrea-Virginica 
Hemocytes from Chesapeake Bay (Virginia) and Apalachicola Bay (Florida)." Diseases of Aquatic Organisms 22(3): 217-225.

Owens, L. and O'Neill, A. (1997). "Use of a clinical cell flow cytometer for differential counts of prawn Penaeus monodon haemocytes." Diseases of Aquatic Organisms 31(2): 147-153.

Ramon, M. and Richardson, C.A. (1992). "Age-determination and shell growth of Chamelea gallina (Bivalvia, Veneridae) in the Western Mediterranean." Marine Ecology Progress Series 89(1): 1523.

Sequeira, T., Vilanova, M., L.obodoCunha, A., Baldaia, L. and AralaChaves, M. (1995). "Flow cytometric analysis of molt-related changes in hemocyte type in male and female Penaeus japonicus." Biological Bulletin 189(3): 376380.

Shapiro, H.M. (1995). "Practical flow cytometry". In: Shapiro, H. (editor). Wiley-Liss: New York. p. 542.

Shapiro, H.M. (2003). "Practical flow cytometry". Wiley, Hoboken, New Jersey.

Smith, V. J. and Soderhall, K. (1983). "Induction of degranulation and lysis of haemocytes in the freshwater crayfish, Astacus astacus by components of the prophenoloxidase activating system in vitro." Cell and Tissue Research 233(2): 295-303.

Soderhall, K. and Thornqvist, P.O. (1997). "Crustacean immunity--a short review." Developments in Biological Standardization 90: 4551.
Stewart, J.E., Cornick, J.W. and Dingle, J.R. (1967). "An electronic method for counting lobster (Homarus americanus milne edwards) hemocytes and the influence of diet on hemocyte numbers and hemolymph proteins". Canadian Journal of Zoology 45: 291-304.

Sung, H. H. and Sun, R. (2002). "Use of monoclonal antibodies to classify hemocyte subpopulations of tiger shrimp (Penaeus monodon)." Journal of Crustacean Biology 22(2): 337-344.

Tsing, A., Arcier, J.M. and Brehelin, M. (1989). "Hemocytes of penaeid and palaemonid shrimps Morphology, cyto-chemistry, and hemograms." Journal of Invertebrate Pathology 53(1): 6477.

Vargas-Albores, F. (1998). "Influence of temperature and salinity on the yellowleg shrimp, Penaeus californiensis Holmes, prophenoloxidase system." Aquaculture Research 29(8): 549553.

Vazquez, L., Alpuche, J., Maldonado, G., Agundis, C., Pereyra-Morales, A. and Zenteno, E. (2009). "Review: Immunity mechanisms in crustaceans." Innate Immunity 15(3): 179-188.

Xian, J.-A., Wang, A-L., Tian, J-X., Huang, J-W., Ye, C-X., Wang, WN. and Sun, R-Y. (2009). "Morphologic, physiological and immunological changes of haemocytes from Litopenaeus vannamei treated by lipopolysaccharide." Aquaculture 298(1-2): 139-145.

Xue, Q. G., Renault, T. and Chilmonczyx, S. (2001). "Flow 
cytometric assessment of haemocyte sub-populations in the European flat oyster, Ostrea edulis, haemolymph." Fish \& Shellfish Immunology 11(7): 557567.

Zhang, Z. F., Shao, M. and Kang, K.H. (2006). "Classification of haematopoietic cells and haemocytes in Chinese prawn Fenneropenaeus chinensis." $\underline{\text { Fish }}$ \& Shellfish Immunology 21(2): 159-169. 
